\title{
Gestão social do desenvolvimento: a exclusão dos representantes dos empresários? 0 caso do Programa Territórios da Cidadania Norte-RJ
}

\author{
Social management of development: the exclusion of business representatives? The case \\ of Programa Territórios da Cidadania Norte-RJ
}

\author{
Felipe Barbosa Zani ${ }^{1}$ \\ Fernando Guilherme Tenório²
}

\section{Resumo}

A concreta incorporação do enfoque territorial como fundamento para as políticas de desenvolvimento rural demanda o rompimento com a tradição vertical e centralizadora das estratégias de desenvolvimento e a consequente valorização das iniciativas locais e da multiplicidade de atores territoriais. No entanto, a trajetória destas políticas releva não apenas o privilégio conferido às organizações vinculadas à agricultura familiar como também a exclusão das organizações representantes dos empresários. Considerada a importância da participação empresarial para o êxito das políticas dessa natureza, analisam-se, neste trabalho, as possibilidades de inclusão das representações dos empresários com vistas ao o pluralismo no âmbito do Programa Territórios da Cidadania Norte-RJ. Foram realizadas entrevistas semiestruturadas, com informações complementadas por análise documental, e tratadas por meio de análise de conteúdo com grade mista baseada no conceito de cidadania deliberativa habermasiano. Os resultados relevam que o modelo de gestão social em vigor não é capaz de promover a concertação social dos atores territoriais. Os representantes da sociedade civil rechaçam indistintamente a inclusão dos empresários por conta de diferenças sociopolíticas, agravadas pela constituição histórica do território. As representações empresariais não estão inseridas no colegiado territorial do Norte-RJ e tampouco conhecem o Programa Territórios da Cidadania. Contudo, estas instituições já estão inseridas em outras instâncias locais de participação social e aceitam a dinâmica que rege estes espaços pautados na gestão social. Tal experimentação democrática pode criar pontos de convergência mínimos que permitam sua inclusão nos colegiados territoriais.

Palavras-chave: Desenvolvimento territorial. Gestão social. Pluralismo. Empresariado.

Artigo submetido em 21 de março de 2011 e aceito para publicação em 04 de agosto de 2011.

1 Mestre em Administração Pública pela Escola Brasileira de Administração Pública e de Empresas (EBAPE) da Fundação Getulio Vargas (FGV); Especialista em Políticas Públicas e Gestão Governamental na Secretaria de Estado de Planejamento e Gestão do Rio de Janeiro. Endereço: Avenida Erasmo Braga, 118, Centro, CEP 2020-000, Rio de Janeiro - RJ, Brasil. E-mail: zzambosa@yahoo.com.br

2 Pós-Doutorado em Administração Pública pelo IGOP/Universitat Autónoma de Barcelona (UAB); Doutor em Engenharia da Produção pela COPPE/Universidade Federal do Rio de Janeiro; Professor Titular da Escola Brasileira de Administração Pública e de Empresas (EBAPE) da Fundação Getulio Vargas (FGV); Coordenador do Programa de Estudos em Gestão Social (PEGS); Bolsista de Produtividade em Pesquisa 2 (CNPq). Endereço: Praia de Botafogo, 190, Botafogo, CEP 22250-145, Rio de Janeiro - RJ, Brasil. Email: fernando.tenorio@fgv.br 


\begin{abstract}
The concrete incorporation of the territorial approach as the basis of rural development policies requires a break with the centered vertical tradition of development strategies and the consequent importance of local initiatives and the multiplicity of territorial actors. However, the trajectory of these policies reveals not only the privilege granted to organizations linked to family farmers as well as the exclusion of organizations representing businessmen. Considering the importance of business participation to the success of such policies, we analyze in this paper the possibilities of including business representatives with a view to pluralism within the Programa Territórios da Cidadania Norte-RJ. We conducted semistructured interviews and documentary analysis; the data collected was treated by content analysis with a combined design developed based on the Habermasian concept of deliberative citizenship. The results reveal that the actual model of social management is not capable of promoting the social consultation of territorial actors. Representatives of civil society reject indistinctly the inclusion of businessmen because of socio-political differences, which are worsened by the historical constitution of the territory. The business representatives are not included in the territorial collegiate North-RJ, nor do they know the Programa Territórios da Cidadania. However, these institutions are already included in other local domains of social participation and accept the dynamics governing these spaces in social management. This democratic experimentation can create minimum points of convergence that allow their inclusion in the territorial collegiate.
\end{abstract}

Keywords: Territorial development. Social management. Pluralism. Business representatives.

\title{
Introdução
}

A doutrina desenvolvimentista respondeu pelos primeiros grandes esforços para a industrialização do país. Defendia a intensa participação estatal como via para a modernização da estrutura produtiva do Brasil, no intuito de irromper com sua tradição periférica agroexportadora no cenário internacional, com a pobreza e com o subdesenvolvimento.

O desenvolvimentismo orientou a condução de programas nacionais de desenvolvimento que, malgrados os êxitos obtidos quanto ao fortalecimento do parque industrial nacional, fracassaram no propósito de redução das desigualdades sociais e regionais. A crise mundial da década de 1970 também contribui para abalar os alicerces das correntes que entendiam o Estado como indutor privilegiado do desenvolvimento, quadro propício para a emergência do modelo neoliberal, defensor da redução, na economia, da intervenção estatal, a quem caberia imperativamente a disciplina e o ajuste das variáveis macroeconômicas.

Mas já na década de 1990, o Estado ressurge como ente importante ao processo de desenvolvimento, embora não mais necessariamente na figura de seu demiurgo, transformação esta que exigiu a incorporação de novas abordagens, como é o caso da que trata do desenvolvimento territorial.

A abordagem territorial é incorporada também pelas políticas de desenvolvimento direcionadas às zonas rurais, sobretudo em razão dos sucessivos fracassos das iniciativas convencionais voltadas à temática. No caso brasileiro, o enfoque territorial é encampado pelo Programa de Desenvolvimento Sustentável dos Territórios Rurais e pelo seu sucessor, o Programa Territórios da Cidadania.

O escopo do projeto de desenvolvimento territorial rural é constituído por questões atinentes à promoção simultânea de transformações produtivas e institucionais, à consideração de alternativas distintas de combate à pobreza, à consideração das identidades territoriais, socialmente construídas, e ao envolvimento da diversidade de atores presentes no território (SEPÚLVEDA et al., 2003; SCHEJTMAN e BERDEGUÉ, 2004).

Portanto tal abordagem acolhe a gestão social, e seu princípio da inclusão, relativo à incorporação dos atores excluídos do processo decisório, e do pluralismo, relativo à multiplicidade de atores na tomada de decisões sobre as políticas públicas - poder público, sociedade civil e mercado (TENÓRIO, 2008; TENÓRIO et al., 2008). 
Apesar dos princípios portados pela gestão social e da adoção da abordagem territorial, a trajetória das políticas de desenvolvimento rural é francamente setorial ao privilegiar as organizações vinculadas à agricultura familiar e excluir as organizações representantes dos empresários, cuja participação nas experiências de desenvolvimento territorial potencializa as possibilidades de êxito destas políticas via fomento de projetos inovadores, diversificação das atividades produtivas etc. (MDA 2005b; ABRAMOVAY, MAGALHÃES e SCHRODER, 2005; CAZELLA, BONNAL e MALUF, 2009).

Com efeito, nem mesmo as organizações empresariais com distribuição nacional, a exemplo das associações comerciais, estão presentes nos colegiados territoriais de participação social previstos para tais políticas (ABRAMOVAY, 2003; ABRAMOVAY e BEDUSCHI FILHO, 2004).

Neste trabalho, pretende-se analisar as possibilidades de inclusão das entidades representantes dos interesses dos empresários com vistas ao pluralismo no âmbito do Programa Territórios da Cidadania Norte-RJ. Para tanto, está estruturado em oito seções, incluindo esta introdução e as referências bibliográficas. Na próxima seção, discorre-se sobre as políticas brasileiras de desenvolvimento rural orientadas pela noção de território, com ênfase no Programa Territórios da Cidadania. A seção 3 introduz o debate sobre gestão social e pluralismo, ao passo que a seção 4 foca nos condicionantes ao envolvimento da multiplicidade de atores territoriais nos espaços de participação social. Na seção 5 , detalha-se a metodologia adotada na pesquisa. Na seção 6, trata-se dos resultados do estudo, incluindo a caracterização do território Norte-RJ, o panorama do programa em questão neste território, além de analisar as percepções dos representantes da sociedade civil e dos empresários sobre temas caros à gestão social em políticas de desenvolvimento territorial rural. Na seção 7, apresentam-se as principais conclusões deste trabalho.

\section{Políticas Públicas de Desenvolvimento Territorial Rural no Brasil}

A doutrina desenvolvimentista orientou a condução da estratégia de desenvolvimento nacional até meados da década de 1970, quando se observa a fragilização do entendimento do Estado enquanto indutor privilegiado, se não exclusivo, do desenvolvimento econômico nacional e que, entre suas inúmeras consequências, demandou medidas de contenção de investimentos públicos, restringindo as possibilidades de intervenção do Estado na economia (SCHNEIDER, 2004; UDERMAN, 2008), a quem caberia concentrar-se na administração das variáveis macroeconômicas (LEITE et al., 2008).

Diante da constatação, já na década de 1990, de que a mera execução de políticas macroeconômicas de orientação monetarista não era condição suficiente para o crescimento econômico, em paralelo à visível deterioração das condições de vida da sociedade, recoloca-se a importância da ação do Estado na direção do desenvolvimento econômico. O escopo de ação do Estado para suportar o desenvolvimento é modificado, exigindo a concepção de novas abordagens teóricas (UDERMAN, 2008), entre as quais ganha visibilidade a ideia de território (MDA, 2005a; BONNAL e MALUF, 2007; LEITE et al., 2008).

Contudo, se há algo consensual em torno da noção de território, trata-se de sua consideração como conceito polissêmico por excelência, abordado por inúmeros campos de conhecimento (FAVARETTO, 2006; HAESBAERT, 2006). Da ótica da Economia, a noção de território ganha estímulo, no final da década de 1970, em torno da empreitada de decifrar as forças motrizes responsáveis por maior dinamismo e capacidade competitiva de determinadas localidades em comparação com outras (VEIGA, 1999; SCHEJTMAN e BERDEGUÉ, 2004). É o caso da experiência da Terceira Itália, cujo arranjo produtivo, flexível e especializado, ancorado nas pequenas e médias empresas, foi considerado mais adequado à instável economia global que se delineava, constituindo-se uma alternativa ao modelo fordista da grande produção em massa (CAZELLA, BONNAL e MALUF, 2009).

Sebastiano Brusco extrai as lições oferecidas pelo caso italiano, enfeixadas em torno de três combinações de compatibilidades necessárias: concorrência e cooperação; conflito e participação; conhecimento local e 
conhecimento científico (VEIGA, 1999). E o denominador comum para estas combinações adviria do papel catalisador desempenhado por projetos elaborados por atores locais.

De imediato, "o diferencial deste processo em relação aos anteriores" é a introdução, pela abordagem territorial, da dimensão da participação social, rompendo com a visão vertical e descendente que marca a ação estatal nas estratégias de desenvolvimento - caso dos grandes projetos de investimento (TENÓRIO, 2007, p. 87). Portanto novos papéis são exigidos do Estado, a quem caberia aprofundar a descentralização, atribuindo competências aos espaços locais; ao passo que, da sociedade civil, exige-se a consolidação de sua função ativa e deliberativa (TORRENS, 2007).

A adoção da noção de território pelo desenvolvimento rural é motivada por sucessivos fracassos das iniciativas convencionais voltadas ao desenvolvimento e combate à pobreza rural, e também por novas tendências verificadas nos domínios do campo - crescimento da participação econômica das atividades rurais não agrícolas, globalização das economias rurais, fortalecimento do discurso da sustentabilidade ambiental etc. (SEPÚLVEDA et al., 2003; SCHNEIDER, 2004; SCHEJTMAN e BERDEGUÉ, 2004; FAVARETO, 2006).

É importante ressaltar que os programas de desenvolvimento territorial rural devem considerar o território como espaço portador de identidade e com um projeto de desenvolvimento socialmente pactuado. Os territórios não existem objetivamente, mas são fruto das intenções compartilhadas entre os atores (SCHEJTMAN e BERDEGUÉ, 2004).

A proposta de desenvolvimento territorial rural começa a ganhar contorno efetivo no Brasil em meados da década de 1990, pelo Programa Nacional de Fortalecimento da Agricultura Familiar ABRAMOVAY, 2003 (PRONAF). Anos depois, no Plano Plurianual (PPA) 2004-2007, é concebido o Programa de Desenvolvimento Sustentável dos Territórios Rurais (PRONAT), vinculado ao Ministério do Desenvolvimento Agrário (MDA). Sua origem remonta ao Pronaf Infra-Estrutura e Serviços, linha do Pronaf que abria espaço para a participação das comunidades por meio dos Conselhos Municipais de Desenvolvimento Rural (LEITE et al., 2008).

O objetivo do PRONAT é "promover o planejamento, a implementação e a autogestão do processo de desenvolvimento sustentável dos territórios rurais e o fortalecimento e dinamização da sua economia" (MDA, 2009). Para fomentar a autogestão, a política prevê a implantação de colegiados territoriais (comumente denominados de Comissão de Implantação das Ações Territoriais - CIAT), instâncias para a prática da gestão social. Suas funções envolvem a coordenação do Plano Territorial de Desenvolvimento Rural Sustentável (PDTRS), priorização dos projetos pretendidos no âmbito do território, e articulação de arranjos institucionais responsáveis pela elaboração dos projetos e avaliação do processo de desenvolvimento (MDA, 2009).

Portanto o PRONAT, além da opção pelo recorte territorial, inovou também ao escolher elaborar a política pública partindo da articulação das dinâmicas sociais locais, favorecendo a participação social (BONNAL e MALUF, 2007). Ao abandonar a lógica vertical e descendente que caracteriza o padrão de intervenção estatal, a implementação do processo de desenvolvimento vincula-se diretamente a estratégias integradoras e democráticas e à capacidade de as iniciativas contarem com as forças sociais dos territórios (TORRENS, 2007).

Os territórios, no âmbito dessa política, são formados por microrregiões rurais, ou seja, espaços que apresentem densidade demográfica menor que $80 \mathrm{hab} . / \mathrm{km}^{2}$ e população média de 50.000 habitantes por município. Segundo o Sistema de Informações Territoriais ${ }^{3}$, foram constituídos 164 territórios rurais, que

3 Dados fornecidos pelo Sistema de Informações Territoriais do MDA. Disponível em $<$ http://sit.mda.gov.br/territorio.php?menu=territorio\&base=1\&informe=s >. Acesso em jan. /2011. 
reúnem 2500 municípios brasileiros (45\% do país), quase 16 milhões de moradores rurais (56\% do país), contemplando $60 \%$ da demanda social do programa, calculada pelo somatório de famílias assentadas e de agricultores familiares.

No transcurso da elaboração do PPA 2008-2011, calcado no arcabouço normativo do Programa Territórios Rurais, propõe-se a implantação do Programa Territórios da Cidadania - PTC - (LEITE et al., 2008; MDA, 2009). Com base em critérios definidos em legislação, os territórios rurais foram priorizados para serem incorporados ao Programa Territórios da Cidadania.

Para França (2010), a gênese dos Territórios da Cidadania não remete unicamente ao PRONAT, embora incorpore diretrizes gerais dos Territórios Rurais, como a abordagem territorial, a visão de rural, e a valorização das identidades. Além disso, os colegiados territoriais e os Planos de Desenvolvimento Territorial mediariam a integração do conjunto de políticas oferecido no âmbito dos Territórios da Cidadania.

O destaque desse programa recai sobre a exigência de articulação de políticas públicas, de diferentes ministérios, na esfera territorial, como tentativa de ampliar o PRONAT para além do Ministério do Desenvolvimento Agrário (FAVARETO, 2009). Ao todo, eram aproximadamente vinte ministérios participantes da política no início de 2011.

O formato da política manteve o colegiado territorial, que deve ser composto paritariamente por representantes governamentais e da sociedade civil organizada em cada território. Os documentos que normatizam a política sugerem a incorporação de novos atores aos colegiados previamente existentes, de modo que sejam contemplados os representantes das três esferas federativas, dos conselhos de políticas públicas, da sociedade civil, de atores econômicos, etc.

O colegiado territorial tem por atribuições precípuas definir o Plano de Desenvolvimento do Território; promover a interação entre gestores públicos e conselhos setoriais; pactuar a agenda de ações; discutir alternativas para o desenvolvimento; exercer o controle social sobre o Programa. Em síntese, é o espaço de planejamento, execução e acompanhamento das ações para o desenvolvimento do território (MDA, 2009).

A centralidade dos colegiados territoriais no ciclo de planejamento e gestão da política reafirma, portanto, a gestão social como elemento conceitual estruturante do Programa Territórios da Cidadania.

\section{O Pluralismo nas Políticas de Desenvolvimento Territorial}

O campo da gestão social começa a ganhar visibilidade nos círculos acadêmicos somente na década de 1990 e, embora venha adquirindo prestígio nos últimos anos, ainda carece de adensamento teórico (FRANÇA FILHO, 2008). Para Tenório e Saravia (2006), há uma confusão generalizada entre a gestão social e a gestão de programas e políticas sociais.

Buscando explorar os elementos que fundamentam a gestão social, tendo por base diferentes campos de conhecimento, Maia (2005) analisa as proposições de Maria do Carmo Brant Carvalho, Tânia Fischer, Paul Singer, Ladislau Dowbor e Fernando Tenório, autores das áreas de Sociologia, Economia, Administração e Serviço Social, indício do potencial interdisciplinar de que goza a gestão social. Seus resultados apontam a gestão social como

Um conjunto de processos sociais com potencial viabilizador do desenvolvimento societário emancipatório e transformador. É fundada nos valores, práticas e formação da 


\begin{abstract}
democracia e da cidadania, em vista do enfrentamento às expressões da questão social, da garantia dos direitos humanos universais e da afirmação dos interesses e espaços públicos como padrões de uma nova civilidade. Construção realizada em pactuação democrática, nos âmbitos local, nacional e mundial; entre os agentes das esferas da sociedade civil, sociedade política e da economia, com efetiva participação dos cidadãos historicamente excluídos dos processos de distribuição das riquezas e do poder. (MAIA, 2005, p. 15-16).
\end{abstract}

O conceito construído por Maia certamente abarca os diversos aspectos que concorrem para a conformação da ideia de gestão social, abrangendo as principais vertentes teóricas voltadas ao tema. Mas essa mesma amplitude torna a proposta imprecisa, cujo tratamento como esforço de síntese parece mais adequado do que propriamente marco conceitual.

França Filho (2008) analisa o tema no nível societário, de abrangência macro, relativo a uma problemática de sociedade, e também no nível organizacional, referente a uma modalidade de gestão específica. Neste último, a gestão social pode ser identificada como um modo específico de gestão organizacional que, idealmente, pretende substituir a lógica instrumental por racionalidades mais sociais, políticas, culturais ou ecológicas.

A gestão social, para o autor, afasta-se da gestão privada, cujas diversas correntes se assemelham pelo modelo de racionalidade orientado ao imperativo econômico, ou seja, à racionalidade instrumental, que reduz as demais esferas - social, política, cultural, ecológica - a aspectos meramente mercantis. "Nesta lógica, todos os meios necessários devem ser arregimentados para a consecução dos fins econômicos definidos numa base técnica e funcional segundo os parâmetros clássicos de uma relação custo-benefício" (FRANÇA FILHO, 2008, p.31).

Serva (1997, p. 22), desenvolvendo as proposições de Guerreiro Ramos e de Habermas, contrapõe a ação racional instrumental à ação racional substantiva. Esta seria a "ação orientada por duas dimensões: na dimensão individual, que se refere à auto-realização, compreendida como concretização de potencialidades e satisfação; na dimensão grupal, que se refere ao entendimento, nas direções da responsabilidade e satisfações sociais", cujas características seriam a autorealização, o entendimento, o julgamento ético, a autenticidade, os valores emancipatórios e a autonomia.

Tenório também explora a relação entre gestão social e gestão privada, ou gestão estratégica na acepção por ele adotada. $\mathrm{O}$ autor entende a "gestão social como processo gerencial dialógico em que a autoridade decisória é compartilhada entre os participantes da ação". A gestão social, ao contrário da gestão estratégica, não mira o adversário, o sucesso. Antes, é uma ação comunicativa visando ao acordo negociado dialogicamente, sem imposição ou coação (TENÓRIO, 2008, p. 158).

Na reflexão teórica oferecida por Tenório, a ideia de gestão social se relaciona com a cidadania deliberativa. Fundamentado nas proposições desenvolvidas por Jürgen Habermas, Tenório (2008, p. 161, grifo dos autores) argumenta que, em linhas gerais, cidadania deliberativa significa dizer que "a legitimidade das decisões políticas deve ter origem em processos de discussão, orientados pelos princípios da inclusão, do pluralismo, da igualdade participativa, da autonomia e do bem comum".

A categoria pluralismo amplia o olhar centrado nas representações dos grupos privilegiados em determinado contexto ao considerar também a diversidade de atores envoltos no processo de decisão das políticas públicas. Já o princípio da inclusão significa considerar, no processo deliberativo, os interesses coletivos do conjunto ampliado da sociedade, sobretudo daqueles atores tradicionalmente excluídos dos diversos sistemas de deliberação (TENÓRIO et al., 2008).

Como fora visto, no âmbito dos Territórios Rurais, iniciativa que fornece as bases para a implementação do Programa Territórios da Cidadania, a ideia de desenvolvimento territorial é indissociável da noção de gestão social (MDA, 2005c). Isto porque "a gestão social se constitui num referencial incontornável para conferir sustentabilidade ao processo de desenvolvimento sustentável" (MDA, 2005a, p. 10), dado que, envolvendo o 
conjunto de atores presentes no território, pode assegurar que as atividades colocadas em prática sejam aderentes ao cotidiano das pessoas, instituições e economias locais.

O envolvimento do conjunto de segmentos sociais do território em prol do desenvolvimento é diretriz alinhada ao pluralismo, pilar da noção de desenvolvimento local com cidadania proposta por Tenório (2007), qual seja, um processo que visa ao desenvolvimento de um território cujos arranjos institucionais são orientados pela cidadania deliberativa, o que, entre outros aspectos, significa partir da ação concertada entre poder público (Executivo, Legislativo e Judiciário), sociedade civil (associações comunitárias, ONGs, sindicatos, etc.) e o mercado (empresários, associações comerciais, indústrias, etc.).

Cazella, Bonnal e Maluf (2009) são contundentes ao afirmar que os casos bem-sucedidos de desenvolvimento territorial contam com a articulação, em algum grau, dos atores públicos, dos atores privados (bancos, empresas, caixas de poupança etc.) e da sociedade civil (sindicatos, associações etc.). José Maria Sumpsi, ao avaliar as políticas europeias voltadas ao tema, chega à mesma constatação de que a presença dos empresários nos colegiados de participação acarreta o alcance de melhores resultados da política (apud ABRAMOVAY, MAGALHÃES e SCHRODER, 2005).

Para Schejtman e Berdegué (2004), embora os segmentos rurais economicamente fragilizados possam adquirir certas competências por sua própria organização, existem outras capacidades determinantes para o desenvolvimento ao qual só terão acesso por meio de articulações com outros atores sociais e agentes econômicos.

Os pactos territoriais de desenvolvimento, dos quais participem as diferentes forças econômicas da região, devem fomentar mudanças técnicas e organizacionais que permitam a inclusão em mercados dinâmicos e a melhoria das condições produtivas aos indivíduos que participam de mercados pouco promissores com base em técnicas tradicionais (ABRAMOVAY, 2003).

Abramovay (2005) destaca ainda que os espaços colegiados previstos para as políticas de desenvolvimento rural territorial, mais que instâncias de controle social, criariam as bases para a inovação, estimulando a elaboração e execução de processos produtivos e de projetos que, na ausência destes espaços, não ocorreriam.

Em síntese, a inserção dos empresários no contexto das políticas de desenvolvimento territorial, em coerência com o ideal pluralista, goza de potencial para propiciar maior distribuição das rendas econômicas auferidas em atividades desenvolvidas no âmbito de iniciativas colaborativas, diversificação do tecido produtivo do território, execução de projetos inovadores, valorização dos ativos territoriais e, com a ampliação dos vínculos sociais das populações mais pobres, a transformação das bases técnicas de produção por eles utilizadas, com consequente aumento das capacidades produtivas, e sua inserção em mercados mais dinâmicos, movimentos com potencial para a redução da pobreza (ABRAMOVAY, 2003; SEPÚLVEDA et al., 2003; SCHEJTMAN e BERDEGUÉ, 2004; ABRAMOVAY, 2005; FAVARETO, 2008).

Embora seja "muito difícil conceber processos de desenvolvimento localizados sem que empresários consolidados possam aí ter participação ativa", como assevera Abramovay (2003, p. 24), o pluralismo nas políticas de desenvolvimento territorial ainda é realidade distante. Em diversos estudos é constatada a composição setorial dos espaços de participação social das políticas de desenvolvimento, ocupados majoritariamente, quando não exclusivamente, por representes da agricultura, sobretudo vinculados à agricultura familiar ${ }^{4}$ (ABRAMOVAY, 2005; FAVARETO, 2008; LEITE et al., 2008).

4 Em alguns casos, o entendimento de agricultura familiar abarca segmentos como índios, negros, quilombolas, extrativistas, silvicultores, aquiculturas, pescadores artesanais, e outras populações tradicionais. 


\section{Condicionantes ao Pluralismo nos Colegiados Territoriais}

$\mathrm{Na}$ busca pelos elementos que conformam o pluralismo nas iniciativas de desenvolvimento territorial, é importante avaliar o desenho destas políticas. A análise da experiência brasileira à luz da experiência internacional, como propõem Abramovay e Beduschi Filho (2004), e Abramovay, Magalhães e Schroder (2005), indica que, no caso nacional, (i) a delimitação dos territórios é essencialmente uma prerrogativa do Governo, e não dos seus protagonistas locais, que se vale de critérios que privilegiam a presença de determinados segmentos sociais, cujo risco é a ausência dos relevantes atores da dinâmica econômica, social, política e cultural nos espaços colegiados; (ii) não há competição no processo de apresentação de projetos, o que reforça sua tendência rotineira e burocratizante, ditada pelas exigências dos órgãos federais de controle; (iii) e a composição sociopolítica dos colegiados é notadamente setorial.

Em síntese, "o sistema de governança destas organizações (conselhos de desenvolvimento rural), seus mecanismos de incentivo são bloqueios ao aproveitamento da energia investida nestes processos participativos [...] um sistema de alocação de recursos cuja governança não se volta para a qualidade, a aprendizagem, a inovação e a avaliação" (ABRAMOVAY, MAGALHÃES e SCHRODER, 2005, p. 16).

Posto o formato da política em questão, Favareto $(2008$, p. 3) defende pela sua inadequação aos requisitos exigidos pelos processos de concertação voltados à articulação dos atores territoriais. Considera que "os modelos de gestão social voltados para maior controle social não necessariamente são os mesmos que precisam ser postos em funcionamento para a coordenação de forças sociais em torno de projetos de desenvolvimento".

Em um cenário marcado simultaneamente pela imperiosa busca por modelos de governança territorial alternativos, que não se esgotem no empoderamento dos segmentos sociais excluídos da dinâmica local (FAVARETO, 2008), pari passu com a saliente escassez de experiências concretas que efetivam o pluralismo neste campo de políticas públicas, optou-se por buscar, na literatura correlata nacional e internacional, alguns dos elementos necessários à adequada arquitetura de instâncias de participação social pautadas pelo pluralismo, bem como os riscos advindos da articulação entre mercado e sociedade civil. Para tanto, foram considerados trabalhos que tratam das parcerias entre mercado e sociedade civil, para as quais são direcionadas uma infinidade de denominações - "parceria", "aliança", "coalizão", "cooperação" etc. (TEODÓSIO, 2009).

Parte dos autores estrangeiros está preocupada com os critical ou key factors for success das parcerias. Ciente do controverso exercício que é a seleção destes fatores de sucesso, Elbers (2004) afirma existir certo consenso em torno de sete pontos: confiança, apoio da alta administração, capacidade de satisfazer as expectativas, objetivos claros, compatibilidade entre os parceiros, partilha da tomada de decisão e transparência.

Parece haver uma convergência entre as proposições nacionais e estrangeiras, na medida em que Meirelles (2005, p. 13) pinça, da bibliografia nacional, recomendações como a "definição de procedimentos claros para a escolha dos parceiros, construção de consensos prévios quanto a expectativas, objetivos, papéis, recursos, estratégias e critérios de avaliação; socialização das informações; e planejamento conjunto".

Essas proposições de corte técnico-gerencialistas levam Teodósio (2008, p. 121) a concluir que "uma constatação decorrente da análise da literatura sobre o tema (parcerias intersetoriais) diz respeito ao caráter normativo e gerencialista de muitas das discussões". Não se trata definitivamente de desprezar os desafios operacionais que marcam as iniciativas de articulação entre mercado e sociedade civil. Pelo contrário, as recomendações presentes na literatura sobre tais parcerias podem ser cruciais para a promoção de avanços rumo à construção de espaços de concertação social voltados às políticas de desenvolvimento territorial rural. 
"No entanto, mais relevante do que os problemas inerentes ao bom azeitamento da operação das práticas colaborativas [...] parecem ser os desafios relacionados às dinâmicas estruturantes das relações de cooperação [...] marcados por relações de poder e dominação na ação social (TEODÓSIO, 2008, p.126)".

Alguns trabalhos da literatura internacional sobre parcerias intersetoriais consideram a dinâmica de poder, ainda que de maneira superficial, preocupando-se em alertar para os riscos envolvidos. Assim o faz Elbers (2004) ao atentar para a possibilidade de as parcerias entre ONGs e mercado estabilizarem-se num sistema top-down. Meirelles (2005) observa, entre os obstáculos presentes nas parcerias, o problema da simetria nas relações de poder.

Sepúlveda et al. (2003) argumentam que a cooperação entre os atores é prejudicada por restrições nos fatores humanos e institucionais, como precária organização social, baixo nível educacional e de desenvolvimento humano, além da fragilidade das instituições, o que contribui para realçar a assimetria de poder.

Nessa linha, Rodriguez (2005) defende que a situação de desigualdade comum às regiões rurais corrói o tecido social enquanto vivência solidária, compartilhada, identitária entre seus atores. A coesão social, entendida como "expresión de comunidades y sociedades unidas por la equidad, la solidaridad, la justicia social, la pertenencia” (SEPÚLVEDA et al., 2003, p. 94) é, pois, função dos níveis de exclusão do território.

Para além da questão do poder, as interações entre organizações da sociedade civil e organizações empresariais são distinguidas por diferenças em termos de cultura (SELSKY e PARKER, 2005); linguagem e jargões, estilos de liderança, tomada de decisão e padrões de operação (ELBERS, 2004) etc.

As análises permitem inferir que, não obstante a relevância, quiçá centralidade, do pluralismo para as políticas de desenvolvimento territorial, as experiências de parceria entre setores não podem ser apreciadas da ótica estritamente gerencial (embora se deva considerá-la) sob o risco de subestimar, ou mesmo desconsiderar, dinâmicas constitutivas da articulação entre mercado e sociedade civil, como a assimetria de poder ou as diferenças de valores e racionalidade portadas por cada ator.

Portanto o desenvolvimento e a continuidade de uma parceria entre ambos os atores dependem, como sintetiza Meirelles (2005), do equacionamento de demandas de duas naturezas: (a) instrumental, relativa a procedimentos de negociação, planejamento, gestão e avaliação do trabalho em conjunto; e (b) política, ideológica e de pressupostos das diferentes organizações, aspectos que geram dificuldades nas negociações de interesses, no trato dos assuntos de poder e das diferenças nas culturas e racionalidades organizacionais (SELSKY e PARKER, 2005; TENÓRIO, 2008; TEODÓSIO, 2008).

Além dos incentivos informados aos atores sociais pelo desenho das políticas de desenvolvimento, sobretudo em relação ao desenho dos espaços de participação social, os atributos e/ou a trajetória dos atores sociais também conformam a amplitude das mudanças pretendidas e o seu modus operandi nas instâncias de pactuação propiciadas por estas políticas públicas.

Bebbigton, Abramovay e Chiriboga (2008) afirmam que a solidez e coesão dos movimentos são função da forte identidade compartilhada por seus membros, que é construída em torno de elementos culturais e sociopolíticos. Por vezes, a força desses vínculos gera discursos que incluem as noções de amigos e inimigos e podem criar enormes barreiras contra qualquer coisa que se assemelhe ou se relacione com o mercado.

Por outro lado, a atuação da representação empresarial no Brasil atende historicamente por um padrão setorial, particularista, e com as demandas dirigidas diretamente ao interior do aparelho estatal (DINIZ, 2004). Tutelados pelo Estado e por regimes autoritários, que desenharam modelos de negociação compartimentados, setoriais e excludentes da classe trabalhadora, ao menos em torno das políticas econômicas mais relevantes, os empresários constituíram-se, na visão da autora, atores desprovidos de visão de conjunto. Em outras palavras, "a falta de tradição de pactos e negociações, envolvendo a disposição para 
transigir e ceder, em benefício de uma agenda comum foi um traço marcante do desenvolvimento histórico da classe empresarial" (DINIZ, 2004, p. 31).

\section{Metodologia}

O objetivo central deste trabalho, de feição exploratória, é analisar as possibilidades de inclusão das entidades representantes dos interesses dos empresários tendo em vista o pluralismo no âmbito do Programa Territórios da Cidadania na região Norte do Estado do Rio de Janeiro. Optou-se pelas concepções de inclusão e pluralismo propostas por Tenório et al. (2008), que derivam do conceito de cidadania deliberativa habermasiano.

Pautando-se no referencial teórico adotado, propõe-se, neste trabalho, a discussão de duas hipóteses, relacionadas à atuação das representações dos empresários e das representações da sociedade civil participantes do colegiado territorial, quais sejam:

- os representantes dos empresários não se inserem nas diferentes instâncias de participação social, inclusive nos colegiados territoriais, devido à racionalidade instrumental que, em termos gerais, orienta o padrão de atuação das organizações que representam, divergente da racionalidade substantiva que funda aquelas instâncias, e pelo padrão histórico de representação dos interesses empresarias no Brasil, marcado pela incidência direta no aparelho do Estado, de corte particularista;

- os representantes da sociedade civil participantes do colegiado territorial, sobretudo aqueles diretamente relacionados à agricultura familiar, rechaçam a inclusão dos representantes dos empresários no âmbito do Programa Territórios da Cidadania por conta do histórico de setorialização da política, além de apresentarem divergências de natureza política e social com tais atores.

Para o desenvolvimento do trabalho, foram realizadas dezoito entrevistas semiestruturadas, com representantes vinculados:

- ao MDA (2) - Delegacia Federal no Rio de Janeiro;

- a organizações da sociedade civil partícipes da CIAT Norte/RJ (9) - sindicatos; associações de trabalhadores rurais, cooperativas e assentamentos;

- a organizações dos empresários (7) - associações comerciais, câmara de dirigentes lojistas e Federação das Indústrias do Estado do Rio de Janeiro (FIRJAN).

As entrevistas cobriram cinco municípios diferentes do norte fluminense, a despeito daquelas realizadas na capital. Os entrevistados foram selecionados com base no critério da tipicidade, isto é, indivíduos devidamente representativos de suas respectivas organizações de origem, preferencialmente ocupantes de postos de direção, e com significativa trajetória na instituição.

A coleta de dados contou ainda com pesquisa documental. Foram considerados os Documentos Institucionais e Documentos de Apoio que orientam a implementação do Programa Territórios da Cidadania, isto é, seu marco normativo; todas as atas disponíveis relativas às reuniões do CIAT Norte-RJ que abrangem o período de dez./2004 a fev./2010; além do PDTRS Norte-RJ.

Os dados foram tratados qualitativamente, por meio de análise de conteúdo com grade mista (VERGARA, 2006). As categorias e critérios de análise para a avaliação de processos participativos deliberativos foram definidos preliminarmente, extraídos da proposta de Tenório et al. (2008), que os desenvolve com base em 
propostas do Instituto de Governo e Políticas Públicas da Universidade Autônoma de Barcelona, e de autores como Castellà, Jorba, Marti e Parés. Cada categoria apresenta critérios de análise, que foram desdobrados em atributos por meio dos elementos trabalhados no referencial teórico.

Quadro 1

Cidadania deliberativa: critérios de análise

\begin{tabular}{|c|c|c|}
\hline Categoria & Critério & Atributo \\
\hline \multirow{3}{*}{ Pluralismo } & \multirow{3}{*}{$\begin{array}{l}\text { Participação } \\
\text { de diferentes } \\
\text { atores }\end{array}$} & $\begin{array}{l}\text { Envolvimento regular de representações empresariais no Programa Territórios } \\
\text { da Cidadania - PTC }\end{array}$ \\
\hline & & Previsão de envolvimento das representações empresariais no PTC \\
\hline & & Informações detidas pelas representações empresariais referentes ao PTC \\
\hline \multirow{3}{*}{ Inclusão } & \multirow{3}{*}{$\begin{array}{l}\text { Aceitação } \\
\text { Social, } \\
\text { Política e } \\
\text { Técnica }\end{array}$} & $\begin{array}{l}\text { Aceitação do envolvimento da multiplicidade de atores sociais no colegiado } \\
\text { territorial }\end{array}$ \\
\hline & & Aceitação política da gestão social praticada nas instâncias de participação \\
\hline & & $\begin{array}{l}\text { Aceitação do padrão de atuação das representações dos atores territoriais nas } \\
\text { instâncias de participação }\end{array}$ \\
\hline
\end{tabular}

Fonte: Adaptado de Tenório et al. (2008, p. 11).

O critério desenvolvido no âmbito da categoria "pluralismo" diz respeito à "participação de diferentes atores". Como as representações da sociedade civil já se encontram inseridas no colegiado territorial, os atributos elaborados focam unicamente nas representações empresariais, das quais se buscou investigar (i) o grau de envolvimento no colegiado territorial, (ii) a previsão contida no Plano de Desenvolvimento Territorial sobre esta inserção, bem como (iii) o nível de conhecimento que as organizações representantes dos empresários detém acerca do Programa Territórios da Cidadania.

Na categoria "inclusão", o critério considerado refere-se à "aceitação social, política e técnica", cujos atributos estão voltados aos representantes dos empresários, e também aos representantes da sociedade civil. Buscou-se analisar (i) a avaliação dos representantes da sociedade civil sobre a inclusão dos representantes dos empresários no colegiado territorial; (ii) o nível de inserção das representações empresariais em instâncias de participação social, não necessariamente os colegiados territoriais, as motivações que justificam essa eventual inserção, e a aceitação política do modelo de gestão social praticado nestes espaços; e, por fim, (iii) a avaliação que os representantes da sociedade civil e dos empresários emitem entre si acerca do padrão de atuação nas instâncias de participação social.

\section{Análise dos Resultados}

Com uma população de aproximadamente 750 mil habitantes, o Território da Cidadania Norte-RJ é composto por nove municípios, a saber, Carapebus, Campos dos Goytacazes, Cardoso Moreira, Conceição de Macabú, Macaé, Quissamã, São Francisco de Itabapoana, São Fidélis e São João da Barra. 
A cultura de cana de açúcar para exportação constitui-se no primeiro ciclo econômico expressivo da região, conferindo-lhe a condição de um dos espaços canavieiros mais tradicionais do Brasil (CARVALHO et al., 2010; MARTINS, 2010). Mas, na metade do século XX, a indústria de açúcar e álcool do norte experimenta significativo refluxo na sua produção (CARVALHO e ALVES, 2010).

A conformação do novo ciclo econômico na região ganha contornos na década de 1970 com os investimentos realizados pela Petrobras na prospecção e na exploração de petróleo na plataforma continental da Bacia de Campos, dando início à instalação da cadeia petrolífera no norte fluminense. A inauguração deste novo ciclo econômico provoca profundas alterações na dinâmica do território (MARTINS, 2010).

Uma das influências mais significativas da indústria petrolífera para a economia da região na atualidade advém do pagamento de royalties aos municípios do norte fluminense, cujos recursos são repassados de maneira desigual entre as localidades, induzindo à competição intrarregional, com impactos sobre a construção de mecanismos de governança regional (MENEZES e NERY, 2010).

O fortalecimento das finanças públicas, bem como das economias locais, não surtiu somente efeitos positivos para o desenvolvimento social. "Apesar de não haver uma análise ampla da utilização direta dos royalties nestes municípios e na Região Norte como um todo", é possível afirmar que "não houve ainda um planejamento capaz de controlar ou mitigar os problemas que começaram a surgir em grande parte dos municípios, a partir da proliferação da população empobrecida, em decorrência dos fluxos migratórios elevados e da distribuição desigual dos benefícios” (MENEZES e NERY, 2010, p. 832).

Os entrevistados situaram os vínculos de identidade territorial do Norte-RJ principalmente a partir das atividades econômicas de destaque na região - produção agrícola e o extrativismo mineral. A distribuição dos royalties na região, segundo os entrevistados, fez emergir duas classes: os municípios ricos e os municípios pobres. "Tem os municípios ricos, que são Macaé, Campos, Carapebus, Quissamã, e os municípios pobres, que são Conceição de Macabú, São Fidelis [...] eu acho que em comum na verdade no território não tem nada" $(\mathrm{SC} 2) .^{5}$

O impacto da indústria petroleira se soma à extensão geográfica do território. Os municípios que, por conta da distribuição dos royalties, são classificados no grupo pobre, não estão localizados em áreas contínuas, o que poderia facilitar ações desenvolvidas em conjunto e o seu fortalecimento. "As ações territoriais têm até sido prejudicadas em função da complexidade geográfica. Conceição de Macabu, que é pobre, está encalacrada no meio de Macaé, Campos, Carapebus, e Quissamã, que são riquíssimas [...] então acontece que Cardoso Moreira e São Fidélis, que são pobres igual a nós, estão do outro lado” (SC1).

Embora "a região tenha uma base cultural muito forte, porque essa não é uma região de formação recente, é de séculos" (EMP5), chama atenção que os entrevistados tenham realçado somente questões identitárias territoriais de ordem econômica em detrimento dos traços culturais, etnográficos, religiosos, etc.

A constatação é relevante dado que, como observam Abramovay e Beduschi Filho (2004, p. 53) acerca da experiência europeia de desenvolvimento territorial, o núcleo da estratégia desta política são as identidades locais, que podem valorizar os produtos da região. "A identidade de uma área é composta de todas as percepções coletivas do passado dos seus habitantes, de suas tradições e de seu know-how, de sua estrutura de produção, sua herança cultural, seus recursos materiais, enfim, seu futuro". Nenhum destes elementos foi explicitamente realçado pelos entrevistados.

${ }^{5}$ A autoria dos trechos das entrevistas é identificada ao final da citação, por siglas que indicam o vínculo do entrevistado com os empresários (EMP), sociedade civil (SC) ou MDA (MDA), aleatoriamente numerados. 


\section{Pluralismo no Território da Cidadania Norte Fluminense: primeiras impressões}

O Território Rural Norte-RJ foi incorporado ao Programa Territórios da Cidadania ainda em 2008. Da demanda social definida pelo Ministério do Desenvolvimento Agrário, o território possui 13,5 mil agricultores familiares; 2,2 mil famílias assentadas; 3,7 mil pescadores, e 5 comunidades quilombolas. ${ }^{6}$

Embora não seja objetivo deste estudo avaliar o desenrolar do programa no território norte fluminense, um balanço preliminar de suas atividades, realizado com base nas entrevistas, indica a existência de "muitas brigas internas no território, e isso compromete a gestão social, porque cada grupo está tentando fazer sua parte, impor os seus projetos, desbancar os outros" (MDA 2). "Ultimamente tem sido fraca a articulação das reuniões. A gente não sabe de reunião. Tem quase um ano, mais ou menos, que eu não vou à reunião" (SC9).

O processo de incorporação do território rural norte fluminense ao Programa Territórios da Cidadania é marcado por resistências. Segundo os entrevistados, a ampliação promovida por essa política em relação ao PRONAT estaria desarticulando o movimento da agricultura familiar em torno do colegiado territorial norte fluminense (CIAT/NF) porque passaram a dividir um espaço, antes apropriado pelo movimento, com atores sociais portadores de outros interesses.

Segundo consta na ata da reunião do colegiado territorial do dia 25 de fevereiro de 2010, que dá o tom do significado atribuído a esse espaço pelos seus participantes, os representantes da sociedade civil rejeitaram a extinção do colegiado de participação social vinculado ao PRONAT, “[...] por entender ser este colegiado um fórum de discussão das questões da agricultura familiar e não podendo de forma alguma ser sucumbido pelo Território da Cidadania, que de forma talvez até do bem vem esvaziando o movimento das organizações da agricultura familiar".

A máxima concessão que os membros do colegiado fazem é pela criação de uma setorial da agricultura familiar no Território da Cidadania, desde que mantida a CIAT do Programa Territórios Rurais, considerada o Fórum da Agricultura Familiar. "Eu não aceito de forma alguma extinguir a discussão do Território Rural. Ele anda em paralelo. O governo extinguiu e criou o Território da Cidadania, mas a gente tem que continuar com o Rural paralelo" (SC1).

A Comissão de Implementação das Ações Territoriais do Norte Fluminense foi instituída no dia 06 de dezembro de 2004. A plenária da CIAT/NF é formada por 50\% de representantes dos beneficiários, $25 \%$ do terceiro setor, e $25 \%$ do poder público, totalizando 52 cadeiras.

Apesar do expressivo número de vagas, não está prevista a inserção de representantes dos empresários. Na verdade, a ata do dia 22 de junho de 2005 deixa claro que, em relação às vagas destinadas aos beneficiários, "se alguma das entidades não representar o agricultor familiar, será sumariamente excluída da CIAT/NF", evidenciando a orientação do espaço. Como alertam Abramovay, Magalhães e Schroeder (2005, p. 33), "a ausência dos empresários dos conselhos afasta estas organizações de sua missão básica, reforça sua natureza reivindicativa e inibe sua capacidade de formulação de projetos inovadores".

Mais do que a ausência nos colegiados territoriais, os representantes dos empresários entrevistados mostraram completo desconhecimento do Programa Territórios da Cidadania. No momento em que foram indagados acerca da iniciativa, os mais esclarecidos se diferenciavam por já terem "ouvido falar".

\footnotetext{
6 Dados fornecidos pelo Sistema de Informações Territoriais do MDA. Disponível em <http://sit.mda.gov.br/territorio.php?menu=territorio\&base=1\&informe=s>. Acesso em jan. 2011.
} 


\begin{abstract}
“A primeira pessoa que está conversando sobre esse assunto aqui é você” (EMP5).
"Eu vou te fazer uma pergunta. O Território da Cidadania abrange o quê? O termo 'cidadania', eu acho que é importante. Mas assim, mais amiúde, o que é que seria o Território da Cidadania?” (EMP2).
\end{abstract}

A parca interação dos representantes empresariais com os colegiados territoriais, contudo, não aparenta ser traço exclusivo do Território da Cidadania Norte Fluminense, como atestam as Boas Práticas Territoriais (MDA, 2010), selecionadas para apresentação no II Salão Nacional dos Territórios Rurais - Territórios da Cidadania em Foco, organizado em 2010.

Entre as 40 experiências apontadas na categoria Dinamização Econômica, dois terços das experiências selecionadas contam, entre suas parcerias, com atores identificados com a iniciativa privada. São comuns as parcerias com o SEBRAE (Serviço Brasileiro de Apoio às Micro e Pequenas Empresas) e com agentes bancários públicos (Banco do Brasil, Banco da Amazônia, Banco do Nordeste, Caixa Econômica Federal), estas últimas talvez firmadas com o intuito de conferir celeridade ao processo de liberação de recursos aos projetos.

Eventualmente são citados outros componentes do Sistema S (SENAR e SENAI) ${ }^{7}$ e a Fundação Banco do Brasil. Por outro lado, praticamente não foram identificadas parcerias com empresas, presentes em somente quatro propostas (Casas Pernambucanas e UNIMED; supermercados e varejistas; FOCO propaganda; e Petrobras). Nenhuma experiência elencou como parceiro a associação comercial, câmara de dirigentes lojistas, federação da indústria, sindicato patronal, ou qualquer outra entidade representativa dos interesses dos empresários.

Constatada a não participação dos representantes empresariais no Território da Cidadania Norte Fluminense, é necessário investigar se há previsão de sua inserção futura no processo, visando a identificar indícios que respondam se esta ausência é meramente conjuntural, fruto da dificuldade em romper com a histórica unidimensionalidade das políticas de desenvolvimento rural, ou se não há interesse futuro efetivo no envolvimento dos empresários.

O Plano de Desenvolvimento Sustentável do Território não prevê concretamente a participação dos representantes dos empresários em seus eixos estratégicos, nem em sua visão de futuro, revelando que a ausência dos empresários na CIAT não é meramente conjuntural, mas uma opção do colegiado.

Novamente, esta não aparenta ser uma característica exclusiva do Território Norte Fluminense. A Síntese dos Planos Territoriais de Desenvolvimento Rural Sustentável elaborada pelo MDA (2007) apresenta diversas informações, entre elas atores envolvidos, visão de futuro e eixos estratégicos, sobre os Planos de 28 territórios prioritários, distribuídos pelas cinco regiões do país.

Semelhante ao observado em Boas Práticas Territoriais, os Planos de Desenvolvimento Territorial citam o envolvimento de diferentes atores. Identificados, porém, com a iniciativa privada, unicamente os agentes bancários públicos e o SEBRAE. Não foi observada a menção a quaisquer empresas, associação comercial, Câmara de Dirigentes Lojistas (CDL) ou congêneres. Na verdade, a expressão "empresário" aparece em somente um dos planos sintetizados no documento.

\footnotetext{
${ }^{7}$ Serviço Nacional de Aprendizagem Rural e Serviço Nacional de Aprendizagem Industrial.
} 


\section{Da aceitação da inclusão dos empresários pelos representantes da sociedade civil}

No caso dos Territórios Rurais, não existe uma norma rígida para a composição dos colegiados territoriais, que podem apresentar diferentes arranjos de acordo com o desejo dos atores sociais locais, mas somente algumas recomendações indicadas pelas resoluções $\mathrm{n}^{\text {os }} 48$ e 52 do CONDRAF (Conselho Nacional de Desenvolvimento Rural Sustentável).

Sugere-se que pelo menos metade das vagas pertença aos representantes da sociedade civil vinculados à agricultura familiar em sentido amplo - índios, negros, quilombolas, extrativistas, silvicultores, aquiculturas, pescadores artesanais, e outras populações tradicionais (MDA, 2006).

Os colegiados devem ser encarados como sistemas abertos que permitam a inserção permanente de novos membros na medida em que se avança na intersetorialidade dos planos territoriais (MDA, 2006). Para os Territórios da Cidadania, em relação ao PRONAT, sugere-se a ampliação do rol de atores envolvidos no colegiado territorial, e a única exigência é a paridade na sua composição.

Embora seja evidente o reconhecimento da importância conferida à participação de diferentes atores, o destaque conferido aos agricultores familiares pode, contudo, limitar a multiplicidade de atores, a despeito das vantagens que tal arranjo representaria para uma política de desenvolvimento rural.

Percebe-se, em ambas as políticas, que a inclusão de representantes dos empresários não é explicitamente mencionada nos documentos normativos, embora o pluralismo seja parcialmente valorizado ao longo deles. Entretanto, há inconteste valorização das representações vinculadas à agricultura familiar. "A orientação é para que o colegiado represente um maior número de atores de um território, que se tornam objetos da política do MDA. São setores de escassos recursos. Não são os empresários, não é pra agricultura patronal" (MDA2).

Para sua efetiva inclusão na política, segundo o entrevistado, a representação empresarial deveria "solicitar junto ao Comitê de Articulação Estadual a participação dele lá, e vai para o Colegiado. O colegiado vai homologar ou vai determinar que participe [...] ela pode ser agregada ao colegiado ou não. Vai depender da forma que ela vai se apresentar" (MDA1). Esse procedimento não consta em nenhuma norma do Programa, nem compete ao Comitê de Articulação Estadual deliberar sobre a composição dos colegiados territoriais.

Assim, a composição dos colegiados privilegia as representações da agricultura familiar, orientação presente nos documentos normativos do Programa, e devidamente assimilada pelos seus executores. Na ausência de marco legal rígido acerca desta composição, os agentes de implementação de tal política podem dificultar ainda mais a inserção dos empresários ao sugerirem que a inclusão destes representantes seja discutida pelos membros do colegiado, que o tem como "Fórum da Agricultura Familiar".

De fato, a composição do colegiado territorial do Norte-RJ, como fora visto, privilegia sobremaneira as representações da agricultura familiar. "Na CIAT a gente excluiu o máximo que pôde a agricultura convencional. A gente coloca mais é agricultura familiar mesmo. Não vamos chamar eles não" (SC1). Grande parte dos entrevistados é radicalmente contra a inclusão de representações empresariais no Programa Territórios da Cidadania, sobretudo quanto à Federação da Agricultura, Pecuária e Pesca do Estado do Rio de Janeiro (FAERJ).

Tem um provérbio aqui na região que diz "em festa de inhambu, macuco não entra”. Então, como eles (empresários) são inhambu, não dá pra gente andar no meio deles [...] respeito a FIRJAN, mas dentro do movimento de agricultura familiar e economia solidária, eu acho que essas pessoas são personas non gratas. ( $\mathrm{SC1})$. 
Sou radicalmente contra (a inclusão de representações empresariais). Porque eles foram contra a gente a vida toda, e são contra, tá? São contra, não adianta. O papel deles é estar contra. Então, inimigo é da porteira pra fora [...]. (SC4).

São instituições que estão até fora do enquadramento da agricultura familiar. Eu achava que não tinha tanta importância participar. (SC9).

Um dos riscos aventados pelos entrevistados acerca dessa inclusão diz respeito ao desequilíbrio entre os recursos de que dispõem as diferentes representações, cuja assimetria conduziria ao desnível de poder no colegiado. "Como eles (empresários) são melhores estruturados, eles acabariam por liderar o processo, e aí a lógica e o objetivo do território estaria ficando em xeque, entendeu? [...] eles não têm a tradição de fazer debate. Costumam chegar com as propostas prontas." (SC5).

Para além das divergências de ordem político-ideológica, os entrevistados também realçam as diferenças sociais, como a linguagem ou a própria vestimenta.

A FIRJAN é muito elitista. Para se ter uma ideia, pra entrar na FIRJAN no Rio de Janeiro, se não estiver de terno, você não entra [...] hoje mesmo cheguei atrasado porque não tinha roupa pra usar na FAERJ. (SC1).

Até o palavreado é diferente. (SC4).

A região toda, não só a FIRJAN, não só o SEBRAE, consideram esse grupo (assentados) como cidadãos de segunda categoria. (SC5).

Como se vai delineando nos trechos acima, os interlocutores não distinguem entre as diferentes modalidades de representação empresarial, avaliando-as de maneira semelhante. "Acho que eles 'rezam na mesma cartilha'. [...] então, pra mim, Associação Comercial, FIRJAN, SEBRAE, FAERJ são tudo uma coisa só. A essência do grupo que eles vivem é contra a agricultura familiar" (SC1)."É tudo farinha do mesmo saco!" (SC4).

Portanto seria confirmada a hipótese que trata da rejeição da inclusão dos representantes empresariais pelas organizações da sociedade civil, indistintamente, tanto por diferenças políticas, marcadamente oriundas dos conflitos em torno de questões rurais, como a reforma agrária, mas também por diferenças sociais, que dizem respeito às desigualdades que permeiam a sociedade brasileira, especialmente o campo, que se veem refletidas, por exemplo, nas diferenças de linguagem realçadas espontaneamente pelos entrevistados. Rodriguez (2005) defende que a situação de desigualdade comum às regiões rurais corrói o tecido social enquanto vivência solidária, compartilhada, identitária entre seus atores.

Especificamente no norte fluminense, as divergências políticas parecem ainda mais evidentes, por conta dos legados do ciclo econômico da cana de açúcar desenvolvido na região, cujo impacto mais nítido é verificado quando se analisam as elites territoriais e a estrutura fundiária.

Por exemplo, as estruturas de poder nessa região. Quem faz parte são as elites, que um pouco mais, um pouco menos, passa pela questão da cana ainda, das fazendas de cana. Na verdade, a questão da terra. Então, isso é uma característica desse território, que ainda está muito viva. Provavelmente, um fazendeiro da FIRJAN não vai querer sentar com o SC4. (SC5).

Não à toa, municípios como Macaé, Campos dos Goytacazes, Cardoso Moreira, São João da Barra e Quissamã apresentavam graus de concentração de terra forte ou muito forte em 1998. Segundo entrevistado 
do MDA, a identidade do território norte se constrói em torno dos assentamentos de reforma agrária, das conquistas de terra, o que pode indicar um histórico de conflitos, não necessariamente violentos, mas com potencial de fraturar a sociedade local.

Além disso, na análise de Martins (2010, p. 8) sobre os grupos de poder desta região, "a tradicional elite ruralista, que sempre comandou a economia e a política local, não se adaptou aos novos tempos e, vivendo de glórias passadas, sempre resistiu às inovações dos métodos produtivos e das relações de trabalho. De maneira antecipada, pode-se afirmar que estes fatores estão vigentes até hoje".

Embora os entrevistados assumam a CIAT como o Fórum da Agricultura Familiar (SC1), com a passagem de Territórios Rurais para Territórios da Cidadania, alguns até aceitam a incorporação de outros atores, abrindo a possibilidade de inclusão dos representantes empresariais, desde que a CIAT seja mantida e que seja criada uma setorial da agricultura familiar para o colegiado do Território da Cidadania. "Mas a gente não concordou com a extinção da CIAT. Aí é clausula pétrea" (SC1).

\section{Da aceitação da participação social pelos representantes dos empresários}

Os representantes dos interesses empresariais, como observado, encontram-se excluídos do colegiado de gestão social do Programa Territórios da Cidadania Norte-RJ, não são assumidamente considerados no Plano Territorial de Desenvolvimento e sequer conhecem a política, embora não sejam estas características privativas da região. Portanto a aceitação política e social destes atores acerca das instâncias participativas foi analisada tendo por base a relação que estabelecem com outros espaços semelhantes aos colegiados territoriais, como fóruns ou conselhos setoriais de políticas públicas.

As associações comerciais de diferentes municípios, a CDL Campista e a FIRJAN possuem representação em uma série de espaços de participação social, como conselho municipal de saúde (EMP1; EMP6), de meio ambiente (EMP1; EMP3; EMP4; EMP5), de agricultura (EMP1; EMP3), entre outros. Na verdade, as entidades "têm [representação em] vários conselhos. Agora, de cabeça aqui, não vou me lembrar de todos" (EMP4).

As representações dos empresários, para além das instâncias em que já se fazem presentes, estão abertas a participar de outros espaços, dado que o entendimento reinante é de que "naquilo que a gente é convidado, a gente comparece [...] porque nós não deixamos de participar de nada que somos convidados" (EMP3); "acho que a gente tem que participar de tudo" (EMP 6).

A interface dessas instituições com os conselhos de políticas públicas não se encerra com a participação. Em um dos casos, as reuniões do conselho são realizadas na sede da própria associação comercial. Como em "qualquer ação, a gente procura trazer, chama à responsabilidade [...] nós somos parceiros de todo mundo, e tudo hoje gira na associação comercial" (EMP1). Tal entidade é conhecida como "Bob Esponja da cidade" (EMP2).

As entidades de representação dos empresários, em regra, foram convocadas pelos próprios colegiados a participar dos conselhos. Na avaliação dos entrevistados, os convites são justificados pela importância das entidades dentro de seus municípios. Tanto é assim que certo entrevistado credita a implantação do Conselho de Segurança Alimentar de Campos à intervenção da entidade empresarial do qual é membro.

Segundo tese defendida por Diniz e Boschi (2000, p. 4), o "Estado exerce importante papel como indutor das formas de organização e de atuação dos empresários como ator coletivo". Dessa ótica, ainda que dirigida pelos autores ao grande empresariado nacional, o movimento de criação e fortalecimento dos espaços de participação social desencadeado pela Carta Magna de 1988, sobretudo os conselhos de políticas públicas, 
pode ter induzido as representações empresariais à busca de sua inserção nestas instâncias que legitimam como fóruns para a deliberação de assuntos públicos.

No entanto, ainda que aceita, essa interpretação não exclui a possibilidade da confluência direta dos interesses empresariais no processo decisório governamental, sem a discussão em instâncias intermediárias, nem a utilização pelos seus representantes de outras formas de relação com o Estado que se desenvolvem ao largo dos conselhos de políticas públicas, como a prática do lobby.

Além de participarem dessas instâncias, as representações empresariais, aparentemente, não refutam a dinâmica da participação social, calcada em valores como a democracia e o diálogo (TENÓRIO, 2008), mesmo que o processo possa ser conflituoso ou vagaroso o que, aliás, poderia refinar a dinâmica participativa.

Na tomada de decisão, a gente vê que é tudo democraticamente, em todos os conselhos que a gente participa. (EMP2).

[O processo deliberativo] é consensual, é consensual [...] funciona. Isso aí funciona. Quando é deliberado, se toma a decisão. Dependendo do poder público, demora um pouco, mas sai. (EMP3).

Quem participa de discussão tem que saber falar e saber ouvir [...] porque aprendi que, em um fórum de discussão, você tem que aprender a ouvir. (EMP5).

Já as organizações que estão na base das representações empresariais são norteadas pela gestão estratégica, fundada no cálculo de meios e fins e na tecnocracia (TENÓRIO, 2008), valores que são considerados por estas instituições durante sua atuação nos colegiados participativos.

[...] comunidade assistida é consumidor em potencial. Então, pra que eu tenha um comércio ativo, eu tenho que me preocupar com a origem, com a vida desse cidadão. [...] eu vou visar é lucro, eu vivo do comércio. Então, a associação tem que participar ativamente de todas as ações do município, seja na área da saúde, seja na área da educação, seja na área da agricultura. (EMP1).

Vamos ganhar na discussão, vamos ver quem tem o melhor argumento, informação técnica mais consistente [...] quem vai para um debate tem que estar preparado pra ele [...]. (EMP5).

A qualificação técnica das entidades participantes dos conselhos só tem a fortalecer a importância do espaço sobre o processo deliberativo. "Você faz uma audiência pública pra discutir o orçamento, quantas as pessoas ali dentro sabem o que é orçamento?" (EMP5). Contudo, a centralidade no debate técnico, como se depreende de algumas falas, pode levar ao comportamento tecnocrático, entendido como "toda ação social implementada sob a hegemonia do poder técnico ou tecnoburocrático" (TENÓRIO, 2008, p. 24), em detrimento da gestão social, em que todos têm direito à fala, sem coação, e "os atores, ao fazerem suas propostas, não podem impor suas pretensões de validade sem que haja um acordo alcançado comunicativamente no qual todos os participantes exponham suas argumentações" (TENÓRIO, 2008, p. 26).

Quanto à aceitação social dos colegiados deliberativos, o que implica aceitação dos diferentes padrões de atuação e racionalidades portados pelos atores que dividem os espaços participativos com as representações empresariais, não houve relato de quaisquer divergências. "O relacionamento é excelente com todas as entidades. Todas as entidades estão voltadas para o desenvolvimento, e todas elas se dão entre si [...] o relacionamento é muito bom. Não existe aí sindicato de empregados, sindicato de empregador. Todos se unem a favor de Campos" (EMP3). 
A opinião das representações empresariais quanto à articulação com outros segmentos sociais é significativamente divergente da opinião manifestada pelas representações da sociedade civil entrevistadas. Isso pode significar a ausência de experiências anteriores de divisão de espaço com organizações mais combativas, por falta de oportunidade ou por opção; ou ainda a dissimulação dos conflitos.

Esse aparente consenso em torno a "princípios genéricos" (participação social, por exemplo) que assumem cada vez mais uma dimensão universal pode, por um lado, esconder divergências importantes que, como não são explicitadas, acabam por impedir que os atores efetivamente conheçam as idéias e posicionamentos reais dos outros. Por outro lado, permitem e estimulam um diálogo inicial entre diferentes atores em torno a pontos de convergência, e não mais em torno às desavenças que marcam as diferenças históricas entre alguns deles. (BEDUSCHI FILHO, 2006, p. 8).

A fuga ao conflito certamente não vai equacioná-lo, mas manter interrompidos os canais de diálogo entre as representações, com prejuízos ao desenvolvimento territorial, e possivelmente induzir os atores a resolver os conflitos por meios que são estranhos à gestão social e à busca por consensos.

Embora não se oponham às demais representações presentes nos colegiados deliberativos, as representações empresariais avaliam que a atuação das associações de bairro, frequentes nos colegiados urbanos, é marcada pelo bairrismo, "eles só veem os problemas deles, que muitas vezes pode até alcançar toda a sociedade, mas, na maioria das vezes, são problemas locais, pontuais" (EMP3); pelo domínio de interesses particulares nas organizações, "o cara sai dali [da associação], se torna político. Ele vai ser um vereador, ele vai ser um cabo eleitoral" (EMP4); e pela cooptação do poder público, "os presidentes das associações recebem um plus da prefeitura [...] e qual é a moral que eles têm pra cobrar do poder público?” (EMP1).

Em síntese, verifica-se que, ao contrário da hipótese apresentada, os representantes dos interesses empresariais do norte fluminense interagem com as instâncias de participação social, sobretudo os conselhos de políticas públicas, e são, inclusive, responsáveis pela fundação de alguns espaços ou por sediar as reuniões dos conselhos. Como fora abordado, isso não significa necessariamente o abandono de outros mecanismos de interlocução com o Estado, nem a adoção integral da proposta de gestão social, tendo em vista que podem orientar sua atuação, nas instâncias deliberativas, por elementos da gestão estratégica. De todo modo, a vivência de gestão social estimulada pela atuação nos conselhos de políticas públicas poderá ser de grande valia no caso da inclusão destas representações nos colegiados territoriais.

\section{Considerações Finais}

Neste trabalho, foram investigadas as possibilidades de inclusão visando ao pluralismo no âmbito do Programa Territórios da Cidadania no Norte do Rio de Janeiro, especificamente em relação às entidades de representação dos interesses empresariais. A importância da participação dos empresários nas políticas de desenvolvimento territorial resvala nas possibilidades de diversificação do tecido produtivo do território, execução de projetos inovadores, valorização dos ativos territoriais, movimentos com potencial para a redução da pobreza.

A incorporação dos empresários no contexto do território rural, no entanto, deve ser cautelosa pelos riscos que pode representar. Além da assimetria de poder em relação às organizações da sociedade civil, existem ainda diferenças em termos de valores, cultura, processo de tomada de decisão, e mesmo linguajar, que, em última instância, refletem o desacordo entre a racionalidade substantiva e a racionalidade instrumental.

E são exatamente estas diferenças que justificam a decisão do MDA em enfatizar nos Territórios da Cidadania os segmentos tradicionalmente excluídos das políticas públicas brasileiras, no intuito de superar a 
pobreza e a desigualdade social no meio rural. Contudo o alcance desses objetivos demanda, em algum grau, o envolvimento dos empresários locais.

Especificamente no caso do norte fluminense, trata-se de uma região fortemente marcada pelos ciclos econômicos da cana de açúcar e do extrativismo mineral, com variados impactos sobre o território, inclusive no que diz respeito às possibilidades de governança, dado que municípios pobres convivem com municípios economicamente dinâmicos, favorecidos pela indústria petrolífera, e que pouco interesse demonstram com relação às políticas territoriais para o desenvolvimento rural.

As entidades representantes dos empresários não compõem o colegiado territorial e nem estão previstas no Plano Territorial de Desenvolvimento Rural Sustentável do Norte-RJ. A maioria das organizações da sociedade civil entrevistadas rechaçou contundentemente a inclusão dos representantes dos empresários, qualquer que seja a organização de origem, no colegiado territorial, intitulado Fórum da Agricultura Familiar, conforme dispõe a hipótese deste trabalho.

As justificativas para a recusa foram de cunho social, ilustradas por diferenças de linguagem ou de vestimenta, típicas de comunidades em que prevalece a desigualdade social, e, principalmente, de cunho político, referentes às lutas do campo e da agricultura familiar, que parecem realçadas no norte fluminense devido à elite conservadora e à estrutura fundiária forjada na região ao longo do ciclo da cana-de-açúcar.

Mas as representações empresariais já se encontram inseridas em outras instâncias de participação social. Além de participarem, aceitam a racionalidade que orienta a dinâmica destes espaços - democracia, formação de consensos, diálogo - ao contrário do que supunha a hipótese deste estudo. Tal experimentação democrática pode criar pontos de convergência mínimos que permitam sua inclusão nos colegiados territoriais, situação ainda inimaginável, dado que os empresários sequer conhecem o PTC. E ainda que tomem ciência da iniciativa, não é possível prever o grau de interesse que manifestariam.

A participação das representações empresariais em instâncias de participação social não significa que não possam acionar outros mecanismos de relação com o Estado, particularistas e de incidência direta no aparelho governamental, que historicamente caracterizam o perfil de atuação das grandes representações dos interesses empresariais. Tampouco significa o abandono completo da racionalidade instrumental inerente às organizações empresariais que representam, cujos elementos podem ser incorporados à atuação nas instâncias colegiadas, como a prevalência do saber técnico.

Para além da experiência dos representantes empresariais com instâncias de participação social, outra possibilidade para a inclusão dos empresários nos colegiados territoriais desvenda-se com a passagem do Programa Territórios Rurais, já apropriado pelas instituições vinculadas à agricultura familiar, para o Programa Territórios da Cidadania, que preconiza a ampliação dos atores envolvidos no processo decisório da política.

Entretanto, no cenário atual, resta claro que o modelo de gestão social praticado no norte fluminense não conseguiu promover a concertação das forças sociais dinâmicas presentes no território, traço fundamental para a concretização das promessas portadas pelas políticas de desenvolvimento com enfoque territorial.

\section{Referências Bibliográficas}

ABRAMOVAY, R. Desenvolver territórios fortalecendo o empreendedorismo de pequeno porte. In: FÓRUM INTERNACIONAL TERRITÓRIO, DESENVOLVIMENTO RURAL E DEMOCRACIA, 1, 2003, Fortaleza. Anais... Brasília: IICA, 2003.

Representatividade e inovação. In: SEMINÁRIO NACIONAL DE DESENVOLVIMENTO RURAL SUSTENTÁVEL, 2005, Brasília. Anais... Brasília: MDA, Condraf, 2005. 
; BEDUSCHI FILHO, L. C. Desafios para o desenvolvimento das regiões rurais. Nova Economia, Belo Horizonte, v. 14, n. 31, set./dez., p. 35-70, 2004.

; MAGAlHÃES, R.; SCHROEDER, M. A agricultura familiar entre o setor e o território. Projeto: As forças sociais dos novos territórios - o caso da Mesorregião Grande Fronteira do Mercosul. São Paulo: FIPE/RIMISP, 2005 .

BEBBIGTON, A.; ABRAMOVAY, R.; CHIRIBOGA, M. Social movements and the dynamics of rural territorial development in Latin America. World Development, v. 36, n. 12, p. 2.874-87, 2008.

BEDUSCHI FILHO, L. C. Os desafios da pesquisa empírica em territórios rurais: atores, interesses e habilidades sociais. 2006. Disponível em: <http://www.rimisp.org/seminariotrm/doc/LUIS-CARLOS.pdf >. Acesso em: jan. 2010.

BONNAL, P.; MALUF, R. S. Políticas de desenvolvimento territorial e a multifuncionalidade da agricultura familiar no Brasil. In: COLÓQUIO INTERNACIONAL SOBRE DESENVOLVIMENTO TERRITORIAL SUSTENTÁVEL, 2007, Florianópolis. Anais... Florianópolis: [s.n], 2007.

BRASIL. MINISTÉRIO DO DESENVOLVIMENTO AGRÁRIO. Secretaria do Desenvolvimento Territorial. Marco Referencial para Apoio ao Desenvolvimento de Territórios Rurais. Brasília: SDT/MDA, 2005a. (Série Documentos Institucionais n. 2).

. Referência para uma Estratégia de Desenvolvimento Rural Sustentável no Brasil. Brasília: SDT/MDA, 2005b. (Série Documentos Institucionais n. 1)

. Referências para a Gestão Social de Territórios Rurais. Brasília: SDT/MDA, 2005c. (Série Documentos Institucionais n. 3)

- Referências para a Gestão Social dos Territórios Rurais - Guia para a Organização Social. Brasília: $\overline{\mathrm{SDT} / \mathrm{M}} \mathrm{DA}, 2006$. (Documento de Apoio n. 3)

Síntese dos Planos Territoriais de Desenvolvimento Rural Sustentável - PTDRS, dos Territórios Prioritários. Brasília: MDA, 2007. 2009

- Territórios da Cidadania. Disponível em: <http:/www.territoriosdacidadania.gov.br>. Acesso em: maio

Catálogo Boas Práticas Territoriais. Brasília: MDA, 2010.

CARVAlHo, A. M. de; ALVES, E. História. In: PLANO DE DESENVOLVIMENTO SUSTENTÁVEL DO NORTE DO ESTADO DO RIO DE JANEIRO - Análise Situacional. V.1. Parte 1. Rio de Janeiro: Governo do Rio de Janeiro, Prodesmar, Petrobras, 2010.

et al. Sistema Físico e Infraestrutura. In: PLANO DE DESENVOLVIMENTO SUSTENTÁVEL DO NORTE DO ESTADO DO RIO DE JANEIRO - Análise Situacional. v. 1. Parte 1. Rio de Janeiro: Governo do Rio de Janeiro, Prodesmar, Petrobras, 2010.

CAZELLA, A. A.; BONNAL, P.; MALUF, R. S. Olhares disciplinares sobre território e desenvolvimento territorial. In: CAZELlA, A. A.; BONNAL, P.; MALUF, R. S. (Org.). Agricultura Familiar: multifuncionalidade e desenvolvimento regional no Brasil. Rio de Janeiro: Mauad X, 2009.

DINIZ, E. Empresário, democracia e desenvolvimento: tendências e desafios no limiar do novo milênio. In: CONGRESSO LUSO-AFRO-BRASILEIRO, 8, 2004, Coimbra. Anais... Coimbra: [s.n], 2004.

. ; BOSCHI, R. Empresários e Poder Legislativo no Brasil Contemporâneo. ENCONTRO ANUAL DA $\overline{\mathrm{ANPOC}}$, 24, 2000, Petrópolis. Anais... Petrópolis: ANPOCS, 2000.

ELBERS, W. Doing business with business: Development NGOs interacting with the corporate sector. 2004. Disponível em: <http://www.evertvrmeer.nl/download.do/id/100105391/cd/true>. Acesso em: jan. 2010. 
FAVARETO, A. Paradigmas do desenvolvimento rural em questão: do agrário ao territorial. 2006.200 f. Tese (Doutorado em Ciência Ambiental) - Programa de Pós-Graduação em Ciência Ambiental, Universidade de São Paulo, São Paulo, 2006.

Três momentos na evolução recente da gestão social do desenvolvimento territorial - dos Conselhos Municipais de Desenvolvimento Rural aos Territórios da Cidadania. In: FÓRUM INTERNACIONAL DESENVOLVIMENTO RURAL SUSTENTÁVEL, 2, 2008, Fortaleza. Anais... Fortaleza: IICA, 2008.

Retrato das políticas de desenvolvimento territorial no Brasil. Documento de trabalho n. 26. 2009, Chile. Disponível em: <http:// www.rimisp.org/.../N26_2009_Favareto_catastro-politicas-desenvolvimento-territorialBrasil_PORT.pdf>. Acesso em: jan. 2010

FRANÇA, C. G. de. Territórios da cidadania e política para gestão pública. [S.1], 2010. Mimeo.

FRANÇA FILHO, G. C. Definindo gestão social. In: SILVA JR., J. et al. (Org.). Gestão Social: práticas em debate, teorias em construção. Fortaleza: Imprensa Universitária/UFC, 2008.

HAESBAERT, R. O mito da desterritorialização: do "fim dos territórios" à multiterritorialidade. 2. ed. Rio de Janeiro: Bertrand Brasil, 2006.

LEITE, S. P. et al. Desenvolvimento territorial: articulação de políticas públicas e atores sociais. In: MIRANDA, C.; TIBURCIO, B. (Org.). Articulação de Políticas Públicas e Atores Sociais (Série Desenvolvimento Rural Sustentável, v. 8). Brasília: IICA, 2008.

MAIA, M. Gestão social: reconhecendo e construindo referenciais. Revista Virtual Textos \& Contextos, n. 4, dez., 2005 .

MARTINS, N. S. F. Economia. In: PLANO DE DESENVOLVIMENTO SUSTENTÁVEL DO NORTE DO ESTADO DO RIO DE JANEIRO - Análise Situacional. v. 1. Parte 1. Rio de Janeiro: Governo do Rio de Janeiro, Prodesmar, Petrobras, 2010.

MEIRELlES, C. Alianças e parcerias - Mapeamento das publicações brasileiras sobre alianças e parcerias entre organizações da sociedade civil e empresas. São Paulo: Imprensa Oficial do Estado de São Paulo: Aliança Capoava, 2005.

MENEZES, K.; NERY, S. Sistema Social. In: PLANO DE DESENVOLVIMENTO SUSTENTÁVEL DO NORTE DO ESTADO DO RIO DE JANEIRO - Análise Situacional. v. 1. Parte 1. Rio de Janeiro: Governo do Rio de Janeiro, Prodesmar, Petrobras, 2010.

RODRIGUEZ, M. P. Gestão Social do Território: Experiências no Estado do Maranhão (Série Desenvolvimento Rural Sustentável, v. 3). Brasília: IICA, 2005.

SCHEJTMAN, A.; BERDEGUÉ, J. A. Desarrollo territorial rural. Santiago: Centro Latino Americano para o Desarrollo Rural, (Caderno Debates y Temas Rurales, n. 1), 2004.

SCHNEIDER, S. A abordagem territorial do desenvolvimento rural e suas articulações externas. Revista Sociologias, Porto Alegre, ano 6, n. 11, jan./jun. 2004.

SELSKY, J. W.; PARKER, B. Cross-Sector partnerships to address social issues: challenges to theory and practice. Journal of Management, v. 31, p. 849-873, 2005.

SEPÚLVEDA, S. et al. El enfoque territorial del desarrollo rural. San José (Costa Rica): IICA, 2003.

SERVA, M. A Racionalidade substantiva demonstrada na prática administrativa. Revista de Administração de Empresas (RAE), São Paulo, v. 37, n. 2, p. 18-30, 1997.

TENÓRIO, F. G. (Org.) Cidadania e desenvolvimento local. Rio de Janeiro: FGV, Ijuí: Ed. Unijuí, 2007. 

2008.

. Um espectro ronda o terceiro setor, o espectro do mercado: ensaios de gestão social. 3. ed. Ijuí: Ed. Unijuí,

; SARAVIA, Enrique. Escorços sobre gestão pública e gestão social. In: MARTINS, Paulo Emílio e PIERANTI, Octavio Penna. Estado e gestão pública: visões do Brasil contemporâneo. Rio de Janeiro: Editora FGV, 2006.

et al. Critérios para a avaliação de processos decisórios participativos deliberativos na implementação de políticas públicas. In: ENCONTRO DE ADMINISTRAÇÃO PÚBLICA E GOVERNANÇA, 2, 2008, Curitiba. Anais... Curitiba: Anpad, 2008.

TEODÓSIO, A. dos S. de S. Parcerias Tri-Setoriais na Esfera Pública: implicações, impasses e perspectivas acerca da provisão de políticas sociais em três experiências. 220f. Tese (Doutorado em Administração de Empresas) - Escola de Administração de Empresas de São Paulo, Fundação Getúlio Vargas, São Paulo, 2008.

TORRENS, J. C. S. Território e desenvolvimento: a experiência de articulação territorial do Sudoeste do Paraná. Curitiba: Deser, 2007.

UDERMAN, S. O Estado e a formulação de políticas de desenvolvimento regional. Revista Econômica do Nordeste, Fortaleza, v. 39, n. 2, p. 232-246, abr./jun. 2008.

VEIGA, J. E. da. A face territorial do desenvolvimento. ENCONTRO NACIONAL DE ECONOMIA, 27, 1999, Belém. Anais... Belém: ANPEC, 1999.

VERGARA, S. C. Métodos de Pesquisa em Administração. 2. ed. São Paulo: Atlas, 2006. 